\title{
Coal Combustion Products
}

Coal-burning powerplants, which supply more than half of U.S. electricity, also generate coal combustion products, which can be both a resource and a disposal problem. The U.S. Geological Survey collaborates with the American Coal Ash Association in preparing its annual report on coal combustion products (Kalyoncu, 2000). This Fact Sheet answers questions about present and potential uses of coal combustion products.

\section{What are coal combustion products?}

Coal combustion products (CCP's) are the inorganic residues that remain after pulverized coal is burned. Coarse particles (bottom ash and boiler slag) settle to the bottom of the combustion chamber), and the fine portion (fly ash, fig. 1) is removed from the flue gas by electrostatic precipitators or other gasscrubbing systems.

Because of concerns about air quality and acid rain, the U.S. Congress passed the Clean Air Act Amendments of 1990 (Public Law 101-549), which included stringent restrictions on sulfur oxide emissions. Most electric utilities in the Eastern and Midwestern States use bituminous coal having high sulfur contents of 2-3.5 percent. In order to meet the emission standards, many utilities have installed flue-gas-desulfurization (FGD) equipment. The FGD products are included in coal combustion products. The components of CCP's are as follows: fly ash, 57 percent; FGD products, 24 percent; bottom ash, 16 percent; and boiler slag, 3 percent.

\section{What is flue gas desulfurization?}

Flue gas desulfurization is a chemical process to remove sulfur oxides from the flue gas at coal-burning powerplants. Many FGD methods have been developed to varying stages of applicability (Radian Corp., 1983). Their goal is to chemically combine the sulfur gases released in coal combustion by reacting them with a sorbent, such as limestone (calcium carbonate, $\mathrm{CaCO}_{3}$ ), lime (calcium oxide, $\mathrm{CaO}$ ), or ammonia $\left(\mathrm{NH}_{3}\right)$. Of the FGD systems in the United States, 90 percent use limestone or lime as the sorbent (fig. 2). As the flue gas

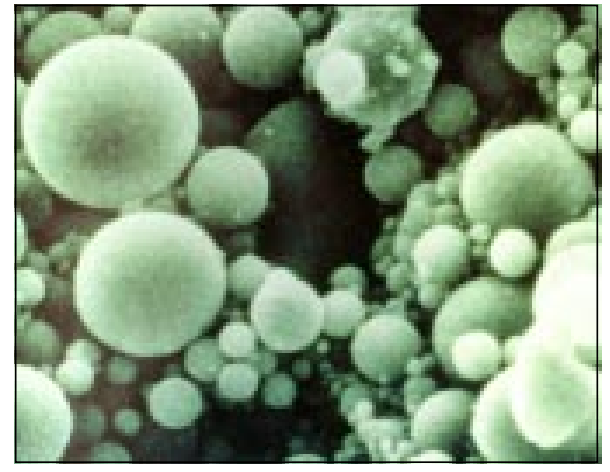

Figure 1. Fly ash from powerplants contains tiny ceramic spheres, typically ranging in diameter from 5 to 75 micrometers, which are called cenospheres; they have many uses. Scanning electron photomicrograph from the American Coal Ash Association.

comes in contact with the slurry of calcium salts, sulfur dioxide $\left(\mathrm{SO}_{2}\right)$ reacts with the calcium to form hydrous calcium sulfate $\left(\mathrm{CaSO}_{4} \cdot 2 \mathrm{H}_{2} \mathrm{O}\right.$, gypsum).

\section{What quantities of CCP's are generated?}

About 100 million metric tons (Mt) of CCP's are generated annually by U.S. coal-burning electric utilities.

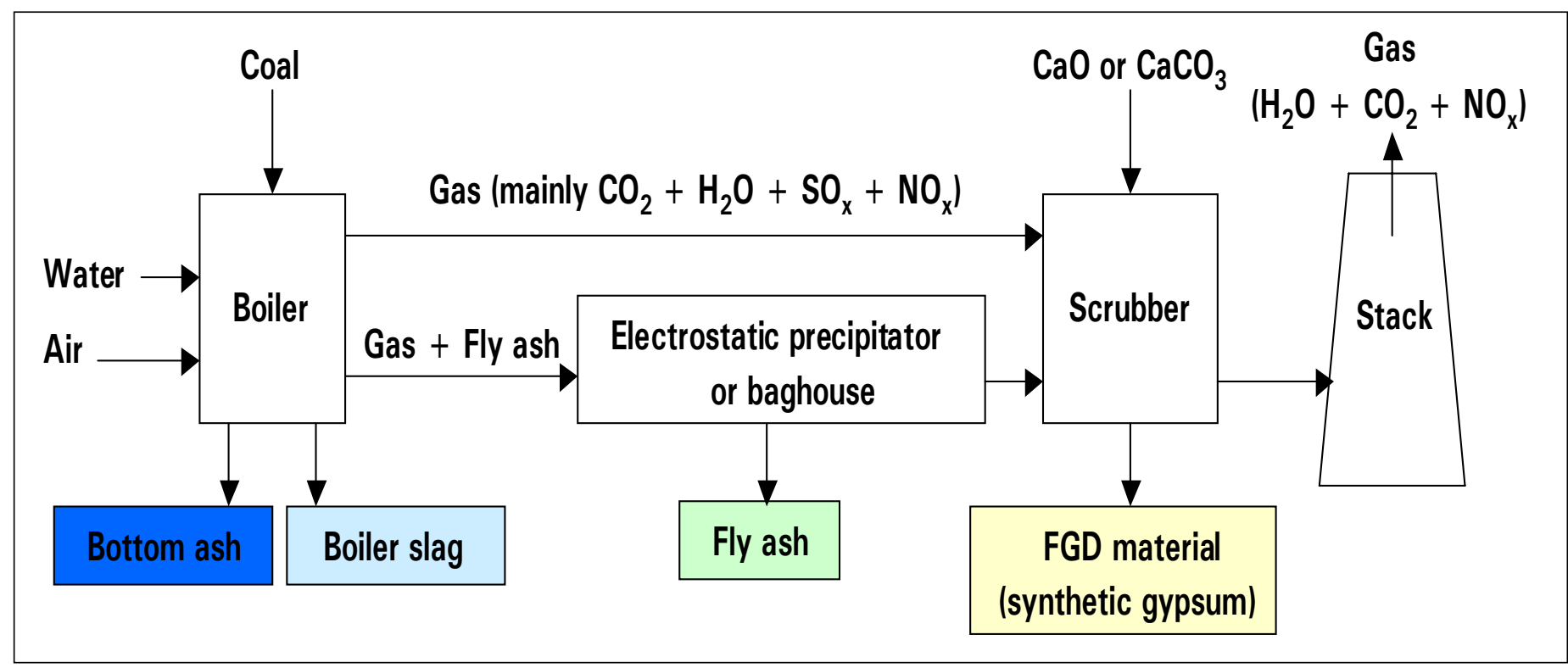

Figure 2. Flow diagram of the flue-gas-desulfurization process based on lime $(\mathrm{CaO})$ or limestone $\left(\mathrm{CaCO}_{3}\right)$, which are the sorbents used by 90 percent of $\mathrm{FGD}$ systems in the United States. 


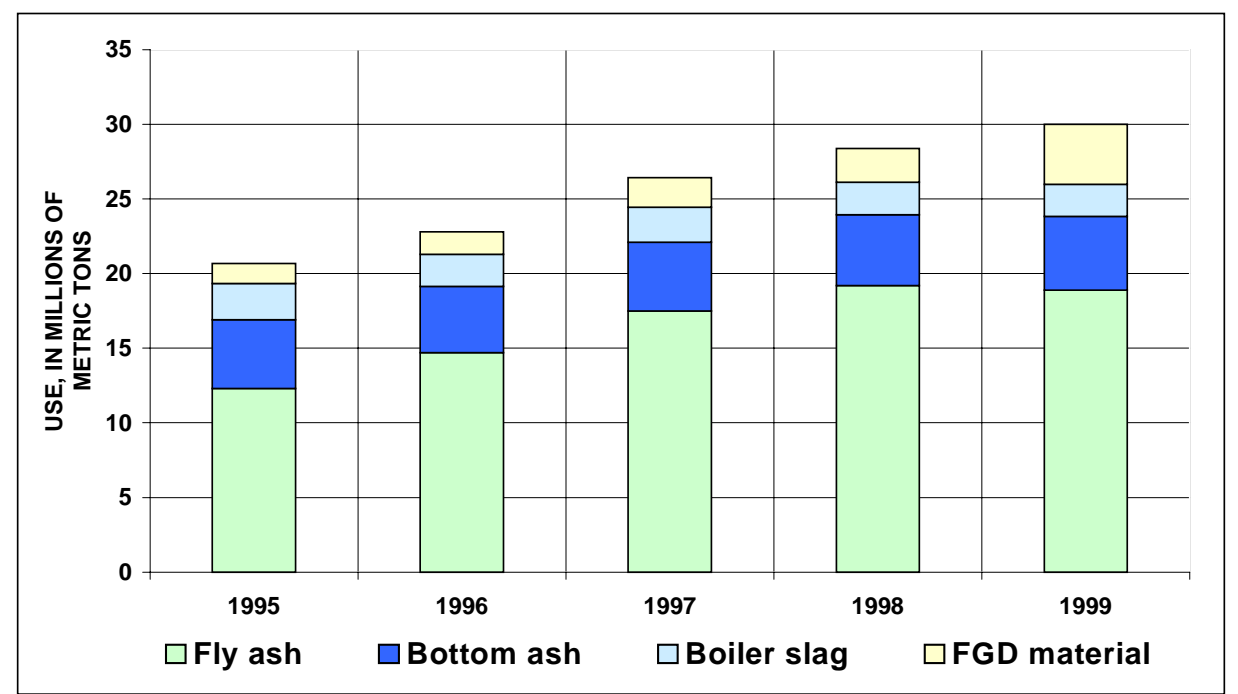

Figure 3. Amounts of coal combustion products used in the United States, 1995-99. Data from the American Coal Ash Association.

\section{What are the uses for CCP's?}

In the United States in 1999, approximately 30 percent of CCP's were used has increased over the years and reached used CCP; in 1999, it made up about 64 percent of the total CCP's used (fig. 4). CCP's are used, in decreasing tonnage, in cement and concrete, structural fill, road bases, agriculture, and other applications. Components of CCP's have different chemical and physical properties that make them suitable for different applications (Kalyoncu, 2000):

- About $57 \mathrm{Mt}$ of fly ash was produced in 1999, and about 19 Mt was used.

The main uses were in concrete, structural fill, and waste stabilization.

- About $15 \mathrm{Mt}$ of bottom ash was produced in 1999, and about 5 Mt was used. The main uses were in structural fill, snow and ice control, road bases,

- About 22 Mt of FGD material was produced in 1999, and about 4 Mt was used, mostly in wallboard manufacture.

- About 2.6 Mt of boiler slag was produced in 1999, and about 2.1 Mt was used, predominantly in blasting grit and roofing applications.

\section{What structural applications use fly ash?}

Fly ash is added to cement and concrete and is used in many large-scale construction projects. Fly ash is a vital rather than discarded. The use of CCP's $30 \mathrm{Mt}$ in 1999 (fig. 3). Fly ash is the most and concrete. component in high-strength concrete in buildings that grace the skylines of major U.S. cities. Fly ash concrete is used in the decks and piers of many highway bridges. Concrete pavements containing fly ash are very durable and cost effective. Between 1950 and 1970, concrete with fly ash contents as high as 50 percent was used in an estimated 100 major dam construction projects. In the construction of Hungry Horse Dam in 1953, for example, 120,000 metric tons of fly ash were used (fig. 5).

\section{What are the benefits of using CCP's in all applications?}

Use of CCP's offers significant environmental and economic benefits. Their long history of successful applications attests to the environmental acceptability of CCP's. When CCP's are used, natural resources can last longer and mining costs can be reduced. In 1999, the productive use of $30 \mathrm{Mt}$ of CCP's saved \$620 million in disposal costs and about 350 acres of landfill space and generated $\$ 150$ million in sales, bringing total benefits to $\$ 770$ million.

\section{... in cement and concrete?}

The largest use of CCP's (mostly fly ash) is in cement and concrete. The CCP's displace portland cement and significantly reduce emissions of carbon dioxide $\left(\mathrm{CO}_{2}\right)$, a greenhouse gas that may be associated with global warming.

Portland cement manufacture requires the burning of fossil fuels and decomposition of carbonates, which release large amounts of carbon dioxide into the atmosphere. Use of CCP's can potentially reduce carbon dioxide emissions by 10 $14 \mathrm{Mt}$ annually. In 1998, 10.5 Mt of fly ash was used in cement and concrete, replacing $7 \mathrm{Mt}$ of portland cement and thereby reducing carbon dioxide emissions by $7 \mathrm{Mt}$.

\section{... in mine reclamation?}

Large cavities left by underground mining make the ground susceptible to subsidence. Acid water draining from some underground mines reaches surface streams and lowers the $\mathrm{pH}$, causing serious ecological damage. Demonstration projects have shown that injection of alkaline CCP's into abandoned mines can

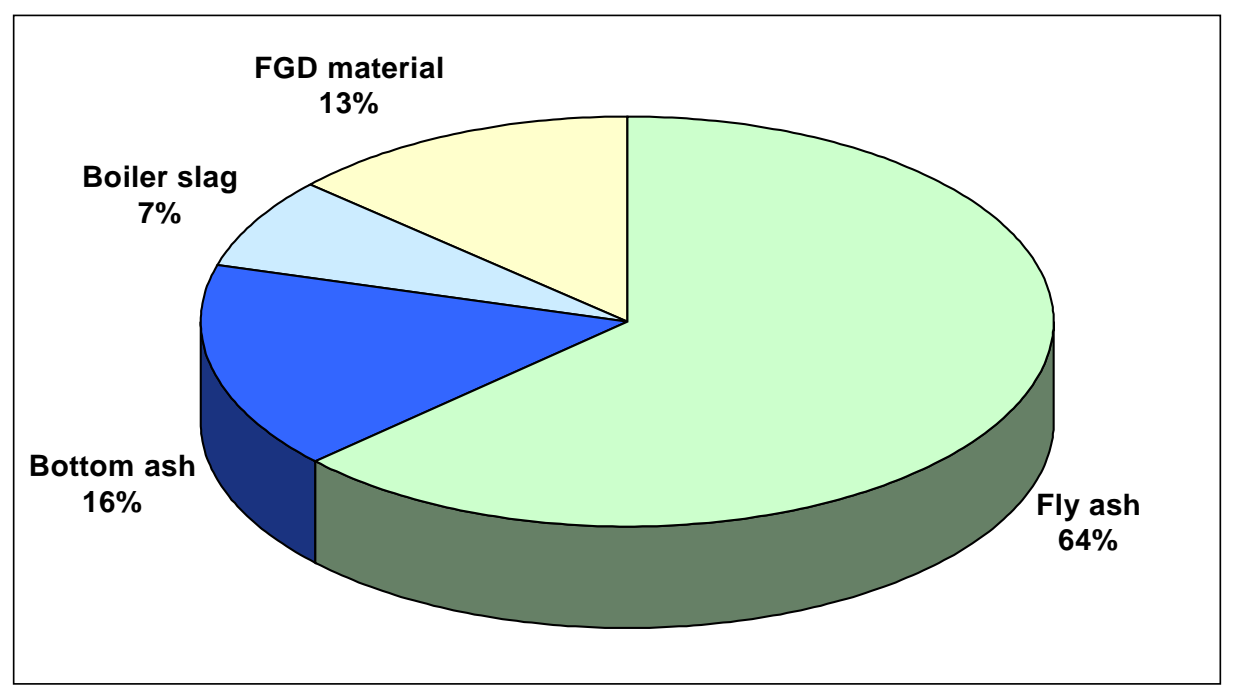

Figure 4. Coal combustion product use by type in the United States, 1999. Data from the American Coal Ash Association. 
help control subsidence and abate acid mine drainage.

\section{... in wallboard manufacture?}

In 1999, about $2.8 \mathrm{Mt}$ of synthetic gypsum produced as FGD material by electric utilities went into wallboard manufacture. The synthetic gypsum meets and often exceeds the specifications for wallboard manufacture. Some wallboard plants that will use 100 percent synthetic gypsum are being built and some have started production (Drake, 1997; Olson, 2000). In 1999, synthetic gypsum accounted for about 17 percent of the total gypsum used in wallboard manufacture, and this figure is expected to increase.

\section{How can cenospheres in fly ash be used?}

Fly ash contains tiny, hollow, particulate ceramic spheres, typically ranging in diameter from 5 to 75 micrometers, which are called cenospheres (fig. 1). They exhibit some unique properties, such as high energy absorption, which results in protection against electromagnetic interference. They are used as fillers in composite materials, in insulations, and in paints. A potential application of cenospheres is as heat-reflecting coatings for rooftops. Widespread use of such coatings could lower average city temperatures in summer and reduce the need for air conditioning.

\section{How can ammonium sulfate FGD's be used in agriculture?}

A flue-gas-desulfurization method popular in Europe uses ammonia $\left(\mathrm{NH}_{3}\right)$ as the sorbent; the FGD product is ammonium sulfate $\left(\left(\mathrm{NH}_{4}\right)_{2} \mathrm{SO}_{4}\right)$. Sulfate is the preferred form of sulfur readily assimilated by crops, and ammonium sulfate is the ideal sulfate compound for soil supplements because it also provides nitrogen from the ammonium. The use of ammonium sulfate in large-scale fertilizer formulations has been growing gradually. This growth provides a market for FGD products and could make FGD processes based on ammonia attractive alternatives to the processes based on lime and limestone.

The estimated worldwide annual shortage of almost $11 \mathrm{Mt}$ of elemental

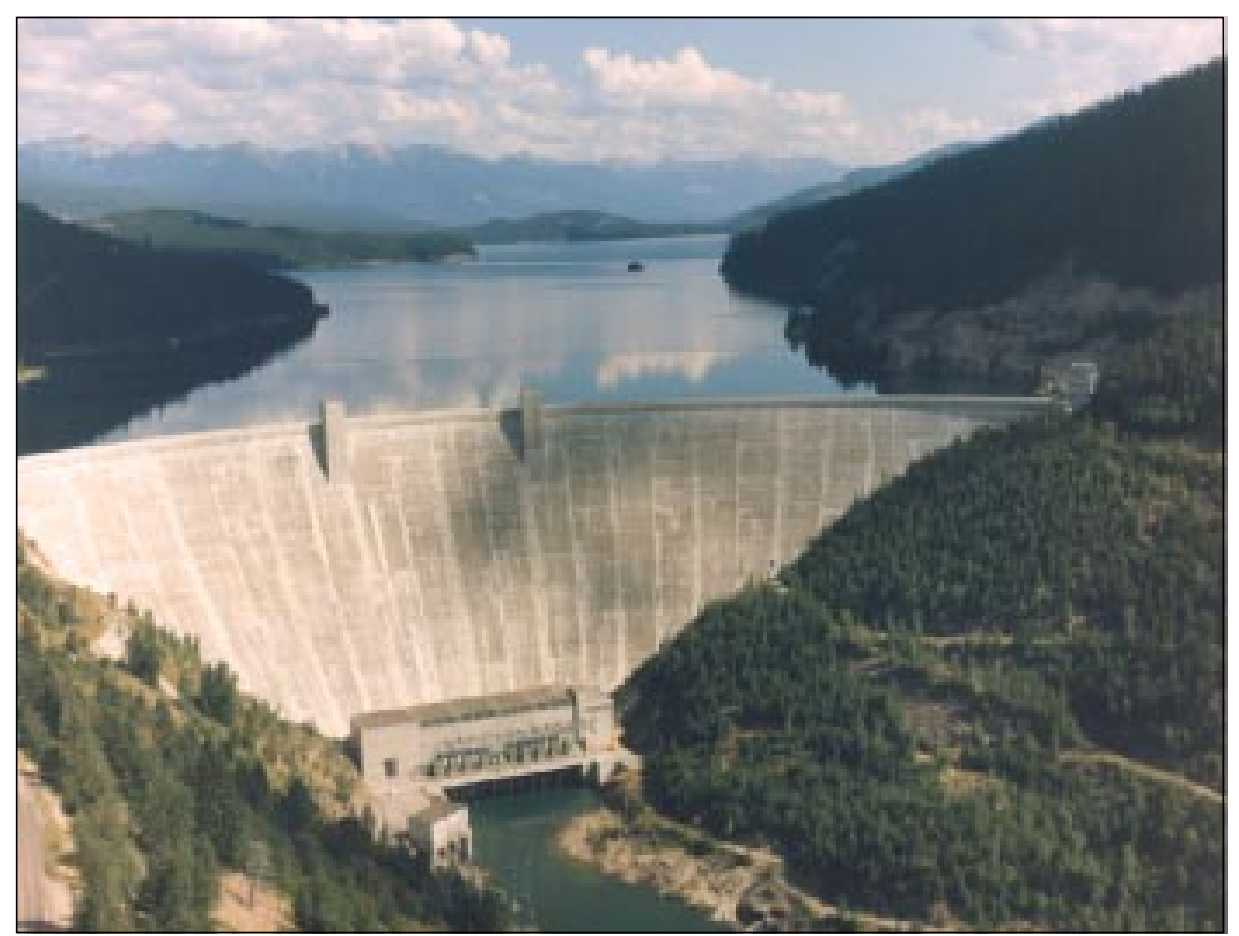

Figure 5. Hungry Horse Dam, Montana, is a thick-arch structure that was built between 1948 and 1953 with concrete containing 120,000 metric tons of fly ash. The use of coal fly ash in cement and concrete displaces portland cement. Photograph from the U.S. Bureau of Reclamation.

sulfur for agricultural applications could be supplied by $45 \mathrm{Mt}$ of ammonium sulfate (Ellison, 1999). This much FGD product could result from 170,000 megawatt-hours (MWh) of electricity production if plants burned coal containing 2.5-3 percent sulfur. A relatively large powerplant generates 1,000 MWh of electricity per year. Thus, 170 large powerplants burning high-sulfur coal and using FGD methods based on ammonia could produce the amount of ammonium sulfate needed for proper plant nutrition.

\section{What research is being done?}

Recent environmental regulations have forced electric utilities to use low$\mathrm{NO}_{\mathrm{X}}$ burners ("low- $\mathrm{NO}_{\mathrm{X}}$ " is a designation for burners that greatly reduce nitrogen oxide emissions). These burners leave some coal unburned, which leads to higher free carbon contents in fly ash and makes the ash unsuitable for use in cement and concrete applications. Many powerplants that previously could earn revenue from selling the fly ash have had to pay for its disposal. However, a novel technology, developed at Pennsylvania State University, can separate the unburned coal from the fly ash and may soon eliminate this problem. Moreover, the coal from the separation process is activated under steam at $850^{\circ} \mathrm{C}$ and can be used in water and gas purification.

Utilities will continue to look for pollution-prevention technologies that will yield smaller quantities of FGD products that will be purer and have higher value than those presently produced. An example is the Basin Electric Cooperative's Dakota Gasification plant in Beulah, N. Dak., where a wet ammonia-based FGD process is used for $\mathrm{SO}_{2}$ removal in combustion of otherwise unsalable fuels derived from gasification of lignite. The resulting ammonium sulfate is sold and used as a sulfur blending stock in fertilizer production.

Research efforts to find new applications and increase the use of CCP's continue. Researchers at the University of Southern Illinois at Carbondale are working on the design for utility poles made of CCP's and organic binders. The researchers expect that the final product will be comparable to or even superior to the traditional creosote-coated wooden poles. In addition to eliminating the need for weatherproofing with creosote, which pollutes rainwater runoff, the $\mathrm{CCP}$ poles would be fireproof and termiteproof, would be cheaper to install, and would be more resistant to damage by humans and animals. It is estimated that 250,000 poles averaging 30-40 feet (9-12 meters) 
in height and another million poles 15-30 feet (4.5-9 meters) in height are used annually in the Midwestern United States alone. Replacing wooden poles with CCP poles could double the use of fly ash while sparing millions of trees annually.

\section{What are the barriers to CCP use?}

There are many technical, economic, regulatory, and institutional barriers to increased use of CCP's. A lack of standards and guidelines for specific applications heads the list of technical barriers. Transportation costs lead the economic barriers, which limit the shipment of CCP's to within about a 50mile (80-kilometer) radius of the powerplants.

The industry's ability to recycle CCP's may be limited by more restrictive environmental controls. In April 2000, the U.S. Environmental Protection Agency (EPA) stated that the use of CCP's does not warrant regulatory oversight but left the door open to stricter regulation of CCP's in the future. A few weeks later, the EPA nearly issued a ruling that would have classified CCP's as hazardous wastes under the Resource Conservation and Recovery Act (RCRA). In May 2000, the EPA reaffirmed its position that CCP's are nonhazardous.

Environmental regulation may also lead to the generation of lower quality, less usable CCP's. As mentioned above, the required use of low- $\mathrm{NO}_{\mathrm{X}}$ burners has resulted in fly ash having an unburned coal content that makes it unsuitable for concrete; until new technologies are applied, this fly ash must be used in other products or disposed of.

Other barriers to CCP use are the RCRA designation of CCP's as solid wastes, regardless of their composition, even when they are used as resources rather than disposed of; the lack of governmental incentive; and the lack of education among the user groups (engineers, contractors, and regulators).

With industry and government cooperation, steps toward increasing CCP use can include (1) establishing a research and development infrastructure to address the technical barriers to $\mathrm{CCP}$ use and to design innovative FGD methods and (2) providing objective scientific information.

\section{What is the bottom line?}

Coal combustion products have many economic and environmentally safe uses. For example, in construction, a metric ton of fly ash used in cement and concrete can save the equivalent of a barrel of oil and can reduce carbon dioxide releases that may affect global warming. The use of CCP's saves landfill space. CCP's can replace clay, sand, limestone, gravel, and natural gypsum, thus preserving the Nation's natural resources and helping to save energy and other costs associated with mining.

\section{References Cited}

Drake, Robert, 1997, Wallboard plants to use $100 \%$ synthetic gypsum: Rock Products, v. 100 , no. 8 , p. 7 .

Ellison, William, 1999, Update on major commercial advancements by ammonia FGD: International Technical Conference on Coal Utilization and Fuel Systems, 24th, Clearwater, Fla., March 8-11, 1999, Proceedings Preprint.

Kalyoncu, R.S. [2000], Coal combustion products: U.S. Geological Survey Minerals Yearbook 1999, v. 1, available online at http:// minerals.usgs.gov/minerals/pubs/ commodity/coal/874499.pdf.

Olson, D.W. [2000], Gypsum: U.S. Geological Survey Minerals Yearbook 1999, v. 1, available online at http://minerals.usgs.gov/minerals/ pubs/commodity/gypsum/ 320499.pdf.

Radian Corporation, 1983, The evaluation and status of the flue gas desulfurization systems, Research Project 982-28: Austin, Tex., Final Report, 631 p.

For more information, please contact:

Rustu S. Kalyoncu

Coal Combustion Products

Commodity Specialist

U.S. Geological Survey

983 National Center

Reston, VA 20192

Telephone: (703) 648-7720

Fax: (703) 648-7722

E-mail: rkayonc@usgs.gov

Donald W. Olson

Gypsum Commodity Specialist

U.S. Geological Survey

983 National Center

Reston, VA 20192

Telephone: (703) 648-7721

Fax: (703) 648-7722

E-mail: dolson@usgs.gov

Web site:

http://minerals.usgs.gov/minerals

Executive Director

American Coal Ash Association

6940 South Kings Highway

Alexandria, VA 22310

Telephone: (703) 317-2400

Fax: (703) 317-2409

Web site: www.acaa-usa.org 